\title{
Design and Manufacturing of Twin-Spindle Drilling Attachment
}

\author{
Sumit M. Naik, Sameer S. Khairnar, Samadhan K. Wagadkar
}

\begin{abstract}
The main purpose of mass production is to produce large quantity of products at lowest possible price. Thus, it is important to design and manufacture such machines or machine attachments that would increase productivity of the components. Combining two operations would result in decreasing the total machining time and thus achieving the objective of increasing the productivity. Therefore, an attempt is made to design and manufacture a twin spindle drilling attachment so that instead of one hole, two holes can be simultaneously produced in a single setting. A simple sun and planet gear arrangement is used to transmit power from main spindle to the drilling spindles. Initially design of various components like gears, input shaft, output shaft and key is done. Then Creo Parametric 2.0 software is used for solid modeling of above mentioned components. Some components like gears, input shaft, output shafts, support plate and keys are manufactured in the workshop while the other remaining components like drill chuck, bearings and drill bit are directly purchased from the market. Final assembly of twin spindle drilling attachment is done by combining all the above mentioned components. Finally, the drilling attachment is installed on the vertical drilling machine.
\end{abstract}

IndexTerms - Creo Parametric 2.0, Productivity, Sun and planet gear, Twin-spindle drilling attachment, Vertical drilling machine.

\section{INTRODUCTION}

\section{A. Drilling machine}

Drilling machine is useful in cutting holes in solid entities like wood, metal and other materials. It has different parts like head, column, base, table, column, sleeve etc. Fig. 1 shows the different parts of drilling machine. It utilizes a drill bit which is a rotary multi-point cutting tool (Deepak et el., 2017). The drill bit is held by the drilling machine with the help of

Manuscript received on 29 June, 2020 and published on July 10, 2020.

Sumit M. Naik, Department of Mechanical Engineering, AISSMS College of Engineering Pune, Maharashtra, India.

Email:smtnk72@gmail.com.

Sameer S. Khairnar, Department of Mechanical Engineering, College of Engineering Pune, Maharashtra, India.

Email: sameerkhairnar28@gmail.com.

Samadhan K. Wagadkar, Department of Mechanical Engineering, College of Engineering Pune, Maharashtra, India.

Email: samadhan63@gmail.com. chuck or Morse taper. Different speeds can be utilized to rotate and feed the drill bit into the workpiece. Other operations like reaming, boring, countersinking, counterboring, spot facing and tapping can also be performed on the drilling machine. While performing the drilling operation, the drill bit is forced against the workpiece and rotated at different speeds depending on the speed range of the drilling machine. The chips are eliminated as the drill bit advances into the workpiece and a hole is produced.

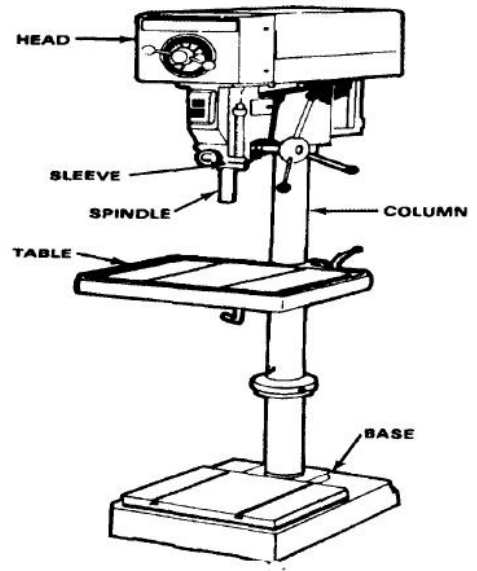

Fig. 1. Parts of drilling machine

In a conventional drilling machine one hole may be drilled in a single operation, but with the use of a drilling attachment, it is possible to drill more than one hole simultaneously in a single setting. Thus, in turn helping in increasing the productivity (Gawande and Trikal, 2016).

\section{B. Multi-spindle drilling attachment}

A multi-spindle drilling attachment can be utilized to simultaneously perform multiple operations in a workpiece. When there is a requirement of repetitive work, these attachments can be effectively utilized. A single motor is used to drive number of drill spindles. All the drill spindles are fed into the workpiece simultaneously. To achieve this, either the work table can be raised or the drill head can be lowered (Bharad et el., 2017). The multi-spindle attachment helps to achieve accurate and identical drilled layouts in mass production. They are commonly used in aircraft and automobile industries. There are classified into two types. The first one is the fixed multi-spindle attachment and the other one is the adjustable multi-spindle attachment (Udgave and Khot, 2016). 


\section{Available online at www.ijrat.org}

\section{CONSTRUCTION AND WORKING OF TWIN} SPINDLE DRILLING ATTACHMENT

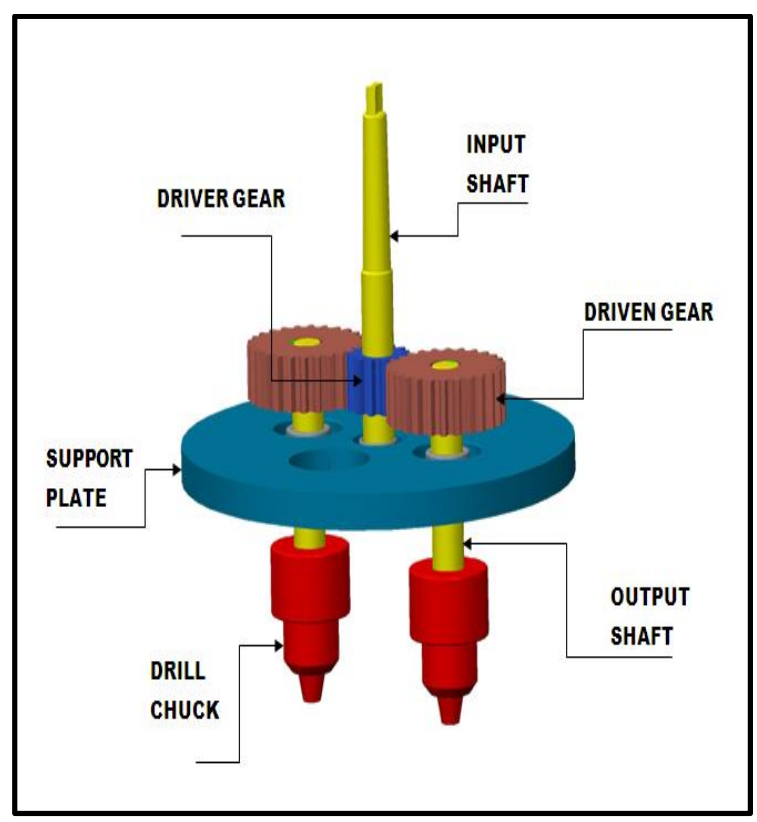

Fig. 2. Schematic of twin spindle drilling attachment

\section{A. Construction}

Fig. 2 shows a schematic arrangement of the twin spindle drilling attachment, which can be used in conjunction with a vertical drilling machine. The input shaft is coupled to the quill of the drilling machine by using a series of Morse tapers. The input shaft also carries the pinion of the gear train. The pinion meshes with two spur gears which are provided with drill chucks for holding the tools. The support plate is meant for providing stability to the entire setup. It carries holes for holding the bearings of the input and output shafts. The support plate is made of mild steel C40.

The input shaft is provided with Morse taper no. 2. It can thus be easily mounted onto the quill of the vertical drilling machine. The input as well as the output shafts are made of mild steel. The output shafts are also tapered accordingly in order to support the drill chucks. The gears mounted on the shaft are spur gears, with speed ratio of 2. Gears are made up of EN-8 material. Keyways are milled in each of the shafts to accommodate sunk keys, so that the relative motion between the shaft and the gears can be prevented. Corresponding keyways are also milled in the shafts.

The bearings provided in the assembly are single row radial deep groove ball bearing. Three such bearings have been used in the setup, one for the input shaft and one each for the two output shafts.

\section{B. Working}

The drive motor of the vertical drilling machine drives the input shaft of the attachment. Thus the pinion mounted on the input shaft also rotates with it and drives the two spur gears mounted on the respective output shafts. Each of the two output shafts are mounted with drill chucks for holding the tools. Thus the tools mounted in the respective chucks also rotate along with the gears and thus perform the required cutting action (Bankar et el., 2013). As the drilling process results into significant heat generation, it is necessary to provide a continuous supply of coolant to the cutting zone.

\section{DESIGN OF VARIOUS COMPONENTS}

\section{A. Design of spur gears}

Properties of Material:

Material used - EN 8,

Ultimate Tensile Strength $\left(\sigma_{\mathrm{ut}}\right)=750 \mathrm{~N} / \mathrm{mm}^{2}$,

Yield Strength $\left(\sigma_{\mathrm{y}}\right)=465 \mathrm{~N} / \mathrm{mm}^{2}$,

Brinell hardness number $(\mathrm{BHN})=250$.

The material used for driver gear and driven gear is same thus we design for pinion.

From (PSG design data book, 2012),

Power required for drilling $\mathrm{P}$ in $\mathrm{kW}$,

$$
\mathrm{P}=\frac{1.25 \times \mathrm{D}_{\mathrm{d}}^{2} \times \mathrm{K} \times \mathrm{N} \times(0.056+1.5 \times \mathrm{S})}{10^{5}}
$$

where, $D_{d}$ - Diameter of hole to be drilled in $\mathrm{mm}$,

$\mathrm{K}$ - Material factor,

$\mathrm{N}$ - RPM during drilling,

$\mathrm{S}$ - Feed rate in $\mathrm{mm} / \mathrm{rev}$,

We select $K=2.05$ from standard tables for work material and value of material factor and $s=0.15$ from the standard table for work material and value of feed in $\mathrm{mm} / \mathrm{rev}$.

$$
\begin{aligned}
& =\frac{1.25 \times 8.5^{2} \times 2.05 \times 900 \times(0.056+1.5 \times 0.15)}{10^{5}} \\
& P=0.4682 \mathrm{~kW}
\end{aligned}
$$

Therefore the power required for two drills will be,

$$
\mathrm{P}=2 \times 0.4682=0.9364 \mathrm{~kW}
$$

By considering the efficiency of gear system as $80 \%$,

$$
\mathrm{P}=0.8 \times 0.9364=0.749 \mathrm{~kW}
$$

Thus, $\mathrm{P}=0.75 \mathrm{~kW}$.

Rated power for drilling machine available $=3.6 \mathrm{~kW}$ Thus the vertical drilling machine can be used for the required drilling operation.

Torque transmitted $(\mathrm{T})$,

$$
\mathrm{T}=\frac{\mathrm{P} \times 60 \times 10^{6}}{2 \times \pi \times \mathrm{N}_{\mathrm{p}}}
$$

where, $\mathrm{N}_{\mathrm{p}}$ - speed of pinion in rpm,

From (2) and $\mathrm{N}_{\mathrm{p}}=1800 \mathrm{rpm}$,

$$
\begin{aligned}
& =\frac{0.75 \times 60 \times 10^{6}}{2 \times \pi \times 1800} \\
\mathrm{~T} & =3978.87 \mathrm{~N}-\mathrm{mm} .
\end{aligned}
$$




\section{Available online at www.ijrat.org}

Tangential force $\left(\mathrm{P}_{\mathrm{t}}\right)$,

$$
\begin{aligned}
P_{t} & =\frac{2 \times T}{D_{p}} \ldots \\
& =\frac{2 \times T}{m \times z_{p}} .
\end{aligned}
$$

where, $\mathrm{D}_{\mathrm{p}}$ - diameter of pinion in $\mathrm{mm}$,

$\mathrm{m}$ - module of gear,

$\mathrm{Z}_{\mathrm{p}}$ - number of teeth in pinion.

The minimum number of teeth for a $20^{\circ}$ full depth involute system of gear teeth in order to avoid interference is 18 . Thus $\mathrm{z}_{\mathrm{p}}=18$.

$$
\begin{aligned}
& =\frac{2 \times 3978.87}{\mathrm{~m} \times 18} \\
\mathrm{P}_{\mathrm{t}} & =\frac{442.09}{\mathrm{~m}} \ldots \ldots
\end{aligned}
$$

We know that, Lewis Form Factor (Y),

$$
\begin{aligned}
\mathrm{Y} & =\pi\left[0.154-\frac{0.912}{\mathrm{z}_{\mathrm{p}}}\right] \ldots \\
& =\pi\left[0.154-\frac{0.912}{18}\right] \\
\mathrm{Y} & =0.3246 \ldots \ldots \ldots \ldots \ldots \ldots
\end{aligned}
$$

Effective load ( $\mathrm{P}_{\text {eff }}$,

$$
\mathrm{P}_{\mathrm{eff}}=\frac{\mathrm{C}_{\mathrm{s}} \times \mathrm{P}_{\mathrm{t}}}{\mathrm{C}_{\mathrm{v}}}
$$

where, $\mathrm{C}_{\mathrm{s}}$ - Service factor

$$
\mathrm{C}_{\mathrm{v}} \text { - Velocity factor }
$$

Assuming the value as $\mathrm{C}_{\mathrm{S}}=1.8$,

Velocity factor $\left(\mathrm{C}_{\mathrm{V}}\right)$,

$$
\mathrm{C}_{\mathrm{v}}=\frac{3}{3+\mathrm{v}}
$$

where, $\mathrm{v}$ - pitch line velocity,

$$
\begin{aligned}
& v=\frac{\pi \times D_{p} \times N_{p}}{60 \times 10^{3}} \ldots \ldots \\
& v=\frac{\pi \times 18 \times \mathrm{m} \times 1800}{60 \times 10^{3}} \\
& v=1.69 \mathrm{~m} \ldots \ldots \ldots \ldots
\end{aligned}
$$

Using (13) in (11),

$$
\mathrm{C}_{\mathrm{v}}=\frac{3}{3+1.69 \mathrm{~m}}
$$

Using (7) and (14) in (10),

$$
\begin{gathered}
\mathrm{P}_{\mathrm{eff}}=\frac{1.8 \times \frac{442.09}{\mathrm{~m}}}{\frac{3}{3+1.69 \mathrm{~m}}} \\
\mathrm{P}_{\mathrm{eff}}=\frac{2387+1345 \mathrm{~m}}{3 \mathrm{~m}} .
\end{gathered}
$$

As the gear and the pinion are made up of the same material, thus the pinion is weaker than the gear.
Therefore, we have to design the pinion (Shingavi et el., 2015).

We know the beam strength equation, $\mathrm{m} \times \mathrm{b} \times \sigma_{\mathrm{b}} \times \mathrm{Y}=\mathrm{P}_{\mathrm{eff}} \times \mathrm{FOS}$.

where, $b$ - face width of gear,

$\sigma_{\mathrm{b}}$ - allowable tensile stress.

Let us adopt,

Factor of safety $=2$,

$$
\begin{aligned}
\mathrm{b} & =12 \mathrm{~m}, \\
\sigma_{\mathrm{b}} & =\frac{\sigma_{\mathrm{ut}}}{3},
\end{aligned}
$$

and using (9) and (15) in (16), we get

$$
\begin{gathered}
\mathrm{m} \times 12 \mathrm{~m} \times \frac{750}{3} \times 0.3246=\frac{2387+1345 \mathrm{~m}}{3 \mathrm{~m}} \times 2 \\
973.8 \mathrm{~m}^{2}=\frac{4744+2690 \mathrm{~m}}{3 \mathrm{~m}} \\
2921.4 \mathrm{~m}^{3}=4774+2690 \mathrm{~m}
\end{gathered}
$$

Solving the above equation we get,

$$
\mathrm{m}=1.44 \mathrm{~mm} \text {. }
$$

Let us take module, $\mathrm{m}=2 \mathrm{~mm}$.

Thus we get,

Pitch Circle Diameter of pinion,

$$
D_{p}=m \times z_{p}=2 \times 18=36 \mathrm{~mm}
$$

Pitch Circle Diameter of gear,

$$
\mathrm{D}_{\mathrm{g}}=\mathrm{m} \times \mathrm{zg}_{\mathrm{g}}=2 \times 36=72 \mathrm{~mm}
$$

Putting the value of $\mathrm{m}=2 \mathrm{~mm}$ in (7),

$$
\begin{aligned}
& \mathrm{P}_{\mathrm{t}}=\frac{442.09}{\mathrm{~m}} \\
& \mathrm{P}_{\mathrm{t}}=\frac{442.09}{2}
\end{aligned}
$$

Thus the tangential load acting on gear is,

$$
\mathrm{P}_{\mathrm{t}}=221.05 \mathrm{~N}
$$

According to standard proportions of gear system, (Nargatti et el., 2016),

Addendum $=\mathrm{m}=2 \mathrm{~mm}$

Dedendum $=1.157 \mathrm{~m}=2.314 \mathrm{~mm}$

Clearance $=0.157 \mathrm{~m}=0.314 \mathrm{~mm}$

Total Depth $=2.157 \mathrm{~m}=4.314 \mathrm{~mm}$

Total Thickness $=1.157 \mathrm{~m}=2.314 \mathrm{~mm}$

Table 1. Specification of pinion and gear

\begin{tabular}{|c|c|c|c|}
\hline $\begin{array}{r}\text { Sr. } \\
\text { No. }\end{array}$ & Gear Name & Pinion & Gear \\
\hline 1 & Material & EN8 & EN8 \\
\hline 2 & Module & 2 & 2 \\
\hline 3 & Number of teeth & 18 & 36 \\
\hline 4 & Pitch circle diameter in $\mathrm{mm}$ & 36 & 72 \\
\hline 5 & Tooth thickness in $\mathrm{mm}$ & 2.314 & 2.314 \\
\hline 6 & Pressure angle in degrees & 20 & 20 \\
\hline
\end{tabular}

The specification of pinion and gear is as shown in Table 1. 


\section{Available online at www.ijrat.org}

\section{B. Design of input shaft}

Properties of Material:

Material used - Mild Steel

Ultimate Tensile Strength $\left(\sigma_{\mathrm{ut}}\right)=450 \mathrm{~N} / \mathrm{mm}^{2}$,

Yield Strength $\left(\sigma_{\mathrm{y}}\right)=280 \mathrm{~N} / \mathrm{mm}^{2}$,

Factor of Safety $=3$,

Tangential force $\left(\mathrm{P}_{\mathrm{t}}\right)=221.05 \mathrm{~N}$,

Power transmitted $(\mathrm{P})=0.75 \mathrm{~kW}$,

Torque transmitted $(\mathrm{T})=3978.87 \mathrm{~N}-\mathrm{mm}$.

We know that, $\mathrm{P}_{\mathrm{r}}=\mathrm{P}_{\mathrm{t}} \times \tan (\theta)$

$$
\begin{aligned}
& =221.05 \times \tan (20) \\
P_{\mathrm{r}} & =80.44 \mathrm{~N}
\end{aligned}
$$

The magnitude of the self-weight of the pinion is very small in comparison to the torque experienced by the shaft and therefore it can be neglected for analysis.

The radial and tangential components of the gear forces will be carried by the shaft. The radial forces will be equal and opposite and therefore will not cause any stresses in the shaft. The tangential forces can be accounted by designing the shaft against torsion failure.

Using ASME code of design,

Allowable shear stress,

$$
\begin{aligned}
\left(\tau_{\mathrm{s}}\right)_{1} & =0.30 \times \sigma_{\mathrm{y}} \\
& =0.30 \times 280 \\
& =84 \mathrm{~N} / \mathrm{mm}^{2} \\
\left(\tau_{\mathrm{s}}\right)_{2} & =0.18 \times \sigma_{\mathrm{ut}} \\
& =0.18 \times 450 \\
& =81 \mathrm{~N} / \mathrm{mm}^{2}
\end{aligned}
$$

Considering minimum of the two values,

(Shinde et el., 2015)

$$
\left(\tau_{\mathrm{s}}\right)_{\mathrm{all}}=81 \mathrm{~N} / \mathrm{mm}^{2}
$$

As we are producing keyway on the shaft, We reduce the above value by $25 \%$.

$\left(\tau_{\mathrm{s}}\right)_{\mathrm{all}}=0.75 \times 81=60.75 \mathrm{~N} / \mathrm{mm}^{2}$

Torque transmitted by the shaft,

$$
\begin{aligned}
T & =\frac{\pi}{16} \times\left(\tau_{s}\right)_{\text {all }} \times d^{3} \\
3978.87 & =\frac{\pi}{16} \times 60.75 \times d^{3}
\end{aligned}
$$

Solving the above equation, we have,

$$
\mathrm{d}=6.93 \mathrm{~mm}
$$

For ease of construction,

We select, $d=20 \mathrm{~mm}$

Thus, diameter of input shaft $=20 \mathrm{~mm}$.

\section{Design of output shaft}

Material used - Mild Steel

Ultimate Tensile Strength $\left(\sigma_{\mathrm{ut}}\right)=450 \mathrm{~N} / \mathrm{mm}^{2}$,

Yield Strength, $\left(\sigma_{\mathrm{y}}\right)=280 \mathrm{~N} / \mathrm{mm}^{2}$,

Factor of Safety $=3$,

Tangential force $\left(\mathrm{P}_{\mathrm{t}}\right)=221.05 \mathrm{~N}$,

Power transmitted $(\mathrm{P})=0.75 \mathrm{~kW}$,

Torque transmitted $(\mathrm{T})=3978.87 \mathrm{~N}-\mathrm{mm}$.
The magnitude of the self-weight of the gear is very small in comparison to the torque experienced by the shaft and therefore it can be neglected for analysis.

In this case the radial forces do not cancel out thus along with the torque experienced by the shaft we have to also consider bending moment caused by the radial force $\mathrm{W}_{\mathrm{R}}$.

The shaft is subjected to a radial force of $80.44 \mathrm{~N}$.

Thus we find out the reactions as $R_{A}=65.69 \mathrm{~N}$ and $\mathrm{R}_{\mathrm{B}}=14.75 \mathrm{~N}$ and the maximum bending moment acting on the shaft is calculated as,

$$
\mathrm{M}=65.69 \times 22=1445.25 \mathrm{~N}-\mathrm{mm}
$$

Thus, the shaft is subjected to a bending moment of $1445.25 \mathrm{~N}-\mathrm{mm}$ in addition to the torque of $3978.87 \mathrm{~N}-\mathrm{mm}$.

We know that equivalent twisting moment,

$$
\mathrm{T}_{\mathrm{e}}=\sqrt{\left(\mathrm{K}_{\mathrm{b}} \mathrm{M}\right)^{2}+\left(\mathrm{K}_{\mathrm{t}} \mathrm{T}\right)^{2}}
$$

where, $K_{b}=$ combined shock \& fatigue factor for bending moment

$\mathrm{K}_{\mathrm{t}}=$ combined shock \& fatigue factor for twisting moment

$$
=\sqrt{(1.5 \times 1445.25)^{2}+(1 \times 3978.87)^{2}}
$$

$$
\mathrm{T}_{\mathrm{e}}=4530.94 \mathrm{~N}-\mathrm{mm}
$$

Also we know that equivalent bending moment, (Bhandari, 2010)

$$
\begin{aligned}
M_{e}= & {\left[\left(K_{b} \times M\right)+\sqrt{\left(K_{b} \times M\right)^{2}+\left(K_{t} \times T\right)^{2}}\right] } \\
= & {[(1.5 \times 1445.25)+} \\
& \left.\sqrt{(1.5 \times 1445.25)^{2}+(1 \times 3978.87)^{2}}\right] \\
& M_{e}=6698.44 \mathrm{~N}-\mathrm{mm}
\end{aligned}
$$

The material used for output shaft is same as input shaft thus the allowable shear stress is similar to input shaft.

$$
\left(\tau_{\mathrm{s}}\right)_{\text {all }}=60.75 \mathrm{~N} / \mathrm{mm}^{2}
$$

and allowable bending stress is given by,

$$
\begin{aligned}
& \left(\sigma_{\mathrm{b}}\right)_{\text {all }}=\frac{\sigma_{\mathrm{ut}}}{F O S} \\
& \left(\sigma_{\mathrm{b}}\right)_{\text {all }}=\frac{450}{3}=150 \mathrm{~N} / \mathrm{mm}^{2}
\end{aligned}
$$

The equivalent twisting moment is also given as,

$$
\begin{aligned}
\mathrm{T}_{\mathrm{e}} & =\frac{\pi}{16} \times\left(\tau_{\mathrm{s}}\right)_{\text {all }} \times \mathrm{D}^{3} \\
4530.94 & =\frac{\pi}{16} \times 60.75 \times \mathrm{D}^{3}
\end{aligned}
$$

Solving the above equation for $\mathrm{D}$, we have,

$$
\mathrm{D}=7.24 \mathrm{~mm}
$$

The equivalent bending moment is also given as,

$$
\begin{aligned}
M_{e} & =\frac{\pi}{32} \times\left(\sigma_{b}\right)_{\text {all }} \times(D)^{3} \\
6698.44 & =\frac{\pi}{32} \times 150 \times(D)^{3}
\end{aligned}
$$

Solving the above equation for $\mathrm{D}$, we have,

$$
\mathrm{D}=7.69 \mathrm{~mm}
$$

Considering the larger of the two values, $\mathrm{D}=7.69 \mathrm{~mm}$. 
For ease of construction,

We select, $\mathrm{D}=20 \mathrm{~mm}$

Thus, diameter of output shaft $=20 \mathrm{~mm}$.

\section{Design of key}

Properties of Material:

Material used - Mild Steel

Ultimate Tensile Strength $\left(\sigma_{\text {ut }}\right)=450 \mathrm{~N} / \mathrm{mm}^{2}$,

Yield Strength, $\left(\sigma_{\mathrm{y}}\right)=280 \mathrm{~N} / \mathrm{mm}^{2}$,

Factor of safety $(\mathrm{FOS})=3$.

Allowable crushing stress,

$\left(\sigma_{c}\right)=\left(\sigma_{y}\right)=280 \mathrm{~N} / \mathrm{mm}^{2}$,

$\left(\sigma_{\mathrm{c}}\right)_{\text {all }}=\frac{\left(\sigma_{\mathrm{c}}\right)}{F O S}=\frac{280}{3}=93.33 \mathrm{~N} / \mathrm{mm}^{2}$

Allowable shear stress,

$\left(\tau_{\mathrm{s}}\right)=0.5 \times\left(\sigma_{\mathrm{y}}\right)=0.5 \times 280=140 \mathrm{~N} / \mathrm{mm}^{2}$,

$\left(\tau_{\mathrm{s}}\right)_{\text {all }}=\frac{\left(\tau_{\mathrm{s}}\right)}{F O S}=\frac{140}{3}=46.67 \mathrm{~N} / \mathrm{mm}^{2}$

Let, $l=$ Length of the key in $\mathrm{mm}$,

$\mathrm{t}=$ Thickness of the key in $\mathrm{mm}$,

$$
\mathrm{w}=\text { Width of the key in } \mathrm{mm} \text {. }
$$

The minimum length of key should be equal to $1.517 \mathrm{~d}$ to ensure a good load distribution over the entire key length when the shaft becomes twisted when loaded in torsion.

Thus $l=1.517 \mathrm{~d}=1.517 \times 20=30.34 \mathrm{~mm}$

Thus we take length of shaft as $31 \mathrm{~mm}$.

The thumb rule dimensions for a sunk key is,

$$
\begin{aligned}
& \mathrm{W}=\frac{d}{4}=\frac{20}{4}=5 \mathrm{~mm}, \\
& \mathrm{t}=\frac{d}{6}=\frac{20}{6}=3.33 \mathrm{~mm} .
\end{aligned}
$$

First we check for failure of key in crushing, Torque transmitted,

$$
\begin{aligned}
\mathrm{T} & =\left(\sigma_{\mathrm{c}}\right)_{\mathrm{act}} \times l \times \frac{t}{2} \times \frac{d}{2} \\
3978.87 & =\left(\sigma_{\mathrm{c}}\right)_{\mathrm{act}} \times 31 \times \frac{3.33}{2} \times \frac{20}{2} \\
\left(\sigma_{\mathrm{c}}\right)_{\mathrm{act}} & =7.70 \mathrm{~N} / \mathrm{mm}^{2} \\
\left(\sigma_{\mathrm{c}}\right)_{\mathrm{act}} & <\left(\sigma_{\mathrm{c}}\right)_{\mathrm{all}},
\end{aligned}
$$

Thus key is safe under crushing load.

Now we check failure of key in shear,

Torque transmitted,

$$
\begin{aligned}
\mathrm{T} & =\left(\tau_{\mathrm{s}}\right)_{\text {act }} \times l \times \mathrm{w} \times \frac{d}{2} \\
3978.87 & =\left(\tau_{\mathrm{s}}\right)_{\mathrm{act}} \times 31 \times 5 \times \frac{20}{2} \\
\left(\tau_{\mathrm{s}}\right)_{\mathrm{act}} & =2.56 \mathrm{~N} / \mathrm{mm}^{2} \\
\left(\tau_{\mathrm{s}}\right)_{\mathrm{act}} & <\left(\tau_{\mathrm{s}}\right)_{\text {all }}
\end{aligned}
$$

Thus key is safe under shear load. Final key dimensions, $l=31 \mathrm{~mm}, \mathrm{w}=5 \mathrm{~mm}, \mathrm{t}=3.33 \mathrm{~mm}$.

\section{SOLID MODELING OF DIFFERENT COMPONENTS}

As per the design in previous section, solid modeling of different components of the drilling attachment is done in Creo Parametric 2.0 software.

The CAD model of pinion and gear is as shown in Fig. 3 and Fig. 4 respectively. The pinion and gear are provided with the keyway in order to fit the key.

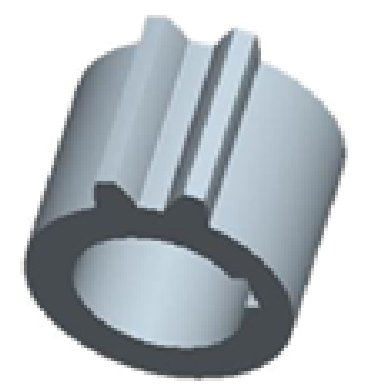

Fig. 3. Solid model of pinion

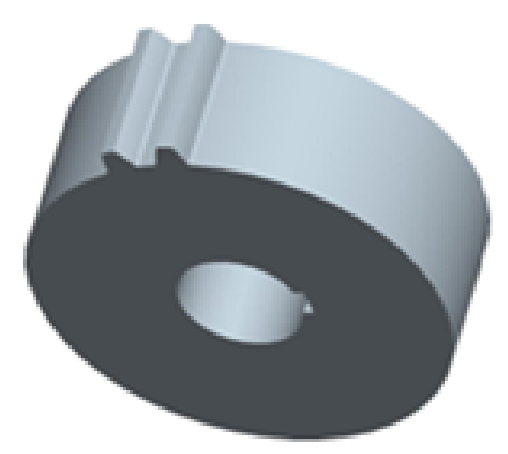

Fig. 4. Solid model of gear

The CAD model of input shaft and output shaft are as shown in Fig. 5 and Fig. 6 respectively. Both the input and output shafts are provided with keyway in order to fit the key.

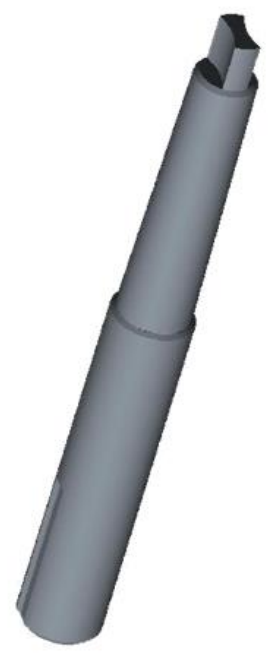

Fig. 5. Solid model of input shaft 


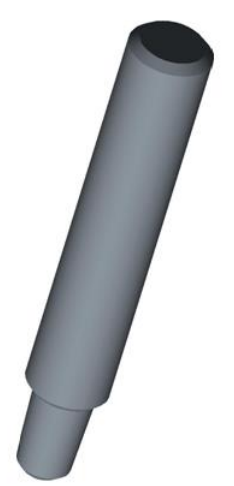

Fig. 6. Solid model of output shaft

The solid model of support plate is as shown in Fig. 7.

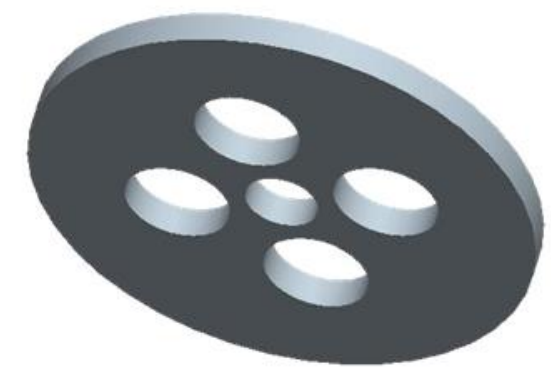

Fig. 7. Solid model of support plate

The solid model of drilling attachment assembly is as shown in Fig. 8.

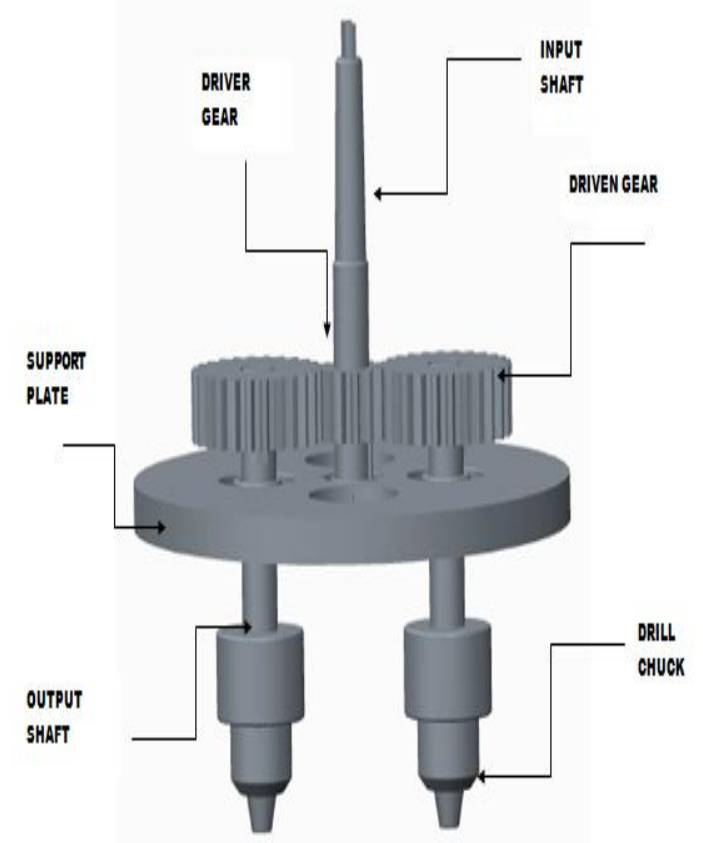

Fig. 8. Solid model of assembly

\section{MANUFACTURING AND ASSEMBLY OF} VARIOUS COMPONENTS

\section{A. Manufacturing of different components}

As per the design specifications given in Table 1, the pinion and gear are manufactured with the help of gear hobbing machine. Then with the help of horizontal broaching machine, the keyway on gear and pinion is produced. The support plate, input shaft and output shaft are manufactured in the $\mathrm{CNC}$ machine. The bearings, drill chuck and drill bits are purchased from market.

\section{B. Assembly of components}

After the manufacturing of some components and purchase of other remaining components, assembly of drilling attachment is done. The assembly is done as following:

1. Insert the input shaft bearing and output shaft bearings into the support plate.

2. Fit the input shaft into the corresponding bearing of support plate.

3. Fit the first output shaft into the corresponding bearing of support plate.

4. Fit the second output shaft into the corresponding bearings of support plate.

5. Fit the pinion on input shaft and two gears on output shafts.

6. Insert the key into the shafts and gears.

7. Fit the drill chucks along with drill bit into the output shafts.

Fig. 9 shows the twin spindle drilling attachment installed on the vertical drilling machine.

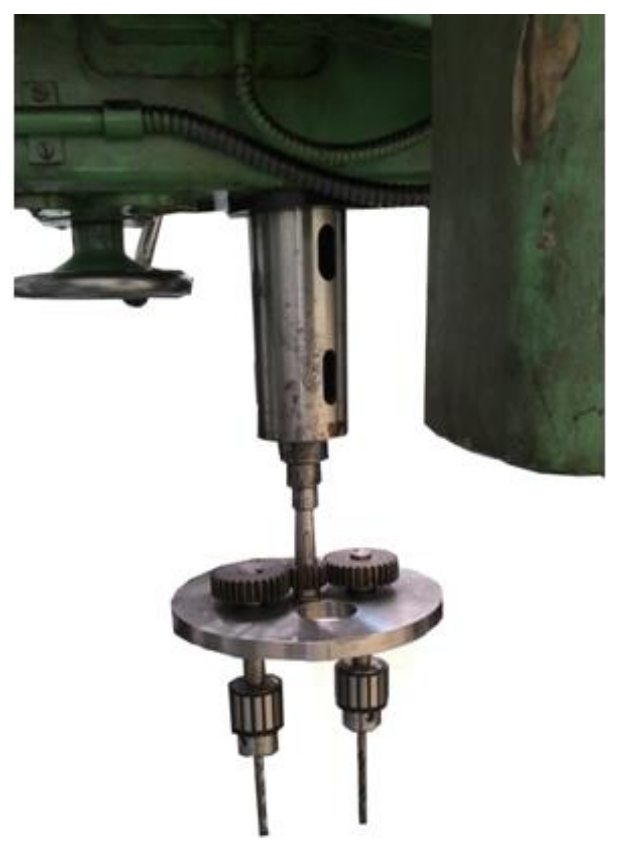

Fig. 9. Final assembly 


\section{Available online at www.ijrat.org}

\section{ADVANTAGES AND DISADVANTAGES}

\section{A. Advantages}

1. The drilling attachment is portable

2. Cheaper as compared to the $\mathrm{CNC}$ machine.

3. It is possible to reduce manufacturing lead time.

4. Operator fatigue can be reduced.

5. Simple to operate.

\section{B. Disadvantages}

1. The pitch circle diameter of the holes of the drilling attachment cannot be changed.

2. Jobs of only a particular dimension can be machined.

3. Overall weight of the attachment is higher than expected.

\section{CONCLUSION}

The twin spindle drilling attachment can be effectively used in conjunction with the vertical drilling machine and can be operated at different speeds that are suitable for drilling. The attachment is portable which gives it an advantage of using it anywhere. It presents an added advantage of being inexpensive over the CNC machining option. Time saving is obtained by a combination of two operations, which also provides with an added benefit of reduced operator fatigue. This setup can help manufacturers reduce cycles of operation and thus increase productivity. Also the attachment enables machining of through holes in workpiece of defined dimensions efficiently, thus it is very useful in mass production.

\section{FUTURE SCOPE}

1. The drilling attachment can be designed for varying center distance between two drilling spindles.

2. Instead of twin spindle, a four spindle attachment can be designed in order to increase productivity further more.

\section{AUTHORS PROFILE}

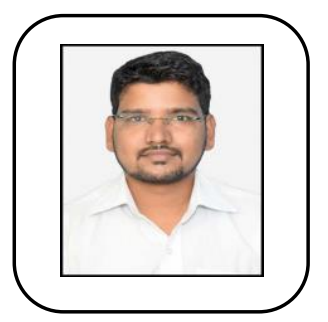

Mr. Sumit M. Naik completed his B. Tech in Mechanical Engineering from College of Engineering Pune and Masters in Design Engineering from Savitribai Phule Pune University, Pune. He has worked in Kalyani Steels Ltd., Pune for 1 year. His area of interest includes design of machine tools and turbo machinery.

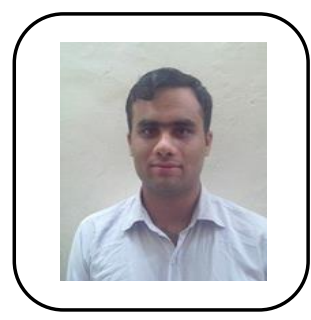

Mr. Sameer S. Khairnar completed his B. Tech in Mechanical Engineering from College of Engineering Pune. He is currently working in Siemens Energy as a Mechanical Design Engineer after having worked in Tata Consulting Engineers Limited.

\section{CONFLICT OF INTEREST}

The authors declare no conflict of interest

\section{REFERENCES}

[1] U. Deepak, C. Tharun Prabhakar, P. M. Prasanth, S. Manikandan, "Design and Fabrication of Multispindle Drilling", International Conference on Latest Innovations in Applied Science, Engineering and Technology, pp. 143-149, March 2017.

[2] Dnyaneshwar B. Bharad, Rahul D. Gawande, Pratik D. Ghangale and Rahul K. Gunjal, "A Paper on Two Spindle Drilling Head", International Research Journal of Engineering and Technology, Vol. 4, Issue 4, pp. 818-821, Apr 2017.

[3] K. I. Nargatti, S. V. Patil and G. N. Rakate, "Design and Fabrication of Multispindle drilling head with varying centre distance", International Journal of Trend in Research and Development, Vol. 3, pp. 506-508, May 2016.

[4] S. R. Gawande and S. P. Trikal, "Design of Special Purpose Multi Spindle Drilling Machine", International Journal of Innovative and Emerging Research in Engineering, Vol. 3, Issue 1, pp. 6-10,2016.

[5] Shinde Nikhil, Vishwakarma Prem, Sanjay Kumar, Godse Rahul, P. A. Patil, "Design \& Development of Twin Drill Head Machine and Drilling Depth Control”, International Journal of Innovative Research in Science, Engineering and Technology, Vol. 5, Issue 5, pp.2946-2957, May 2015.

[6] Prof. A. A. Shingavi, Dr. A. D. Dongare, Prof. S. N. Nimbalkar, "Design of Multiple Spindle Drilling Machine", International Journal of Research in Advent Technology: 1st International Conference on Advent Trends in Engineering, Science and Technology, pp. 37-41, 8 March 2015.

[7] Prof. M. B. Bankar, Prof. P. B. Kadam, Prof. M. R. Todkar, "Improvement in Design and Manufacturing Process of Multiple Spindle Drilling Attachment", IOSR Journal of Engineering, Vol. 3, Issue 1, pp. 38-43, Jan 2013.

[8] A. S. Udgave and Prof. V. J. Khot, "Design and Development of Multi Spindle Drilling Head (msdh)", IOSR Journal of Mechanical and Civil Engineering, pp. 60-69, June 2016.

[9] V.B. Bhandari, "Design of Machine Elements", Third Edition, Tata McGraw Hill Publications, 2010.

[10] Design Data Book of Engineers, PSG College of Technology, Coimbatore, Kalaikathir Achchagam Publications, 2012.

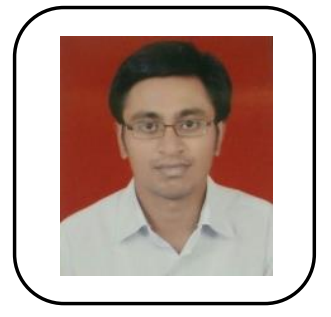

Mr. Samadhan K. Wagadkar completed his B. Tech in Mechanical Engineering from College of Engineering Pune. He has an industrial experience of 1 year in the field of CAD solid modeling. 